\title{
Deshelled Carica papaya Seeds as Natural Coagulant for Improvement Quality of River Water
}

(Biji Carica papaya Terkupas sebagai Bahan Penggumpal Semula Jadi untuk Meningkatkan Kualiti Air Sungai)

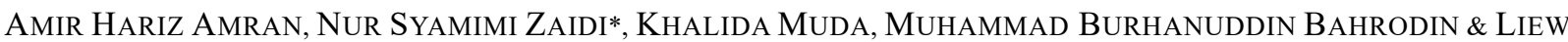 \\ WAI LOAN
}

\section{ABSTRACT}

This study evaluated the efficiency of deshelled papaya seeds as the natural coagulant in improving quality of river water. The deshelled papaya seeds biomass was mainly characterized for functional groups using FTIR, surface charge and protein content. Coagulation and flocculation tests were conducted using batch test for various dosages and pH values. The optimum dosage and $\mathrm{pH}$ were then tested in treating river of Class III to Class $V$. The functional groups in deshelled papaya seeds were $\mathrm{O}-\mathrm{H}, \mathrm{C}=\mathrm{O}$ and $\mathrm{C}$-O groups. The surface charge and protein content was $+0.4 \mathrm{meq} / \mathrm{g}$ and $363 \mathrm{mg} / \mathrm{g}$, respectively. The deshelled papaya seeds coagulant was able to remove turbidity up to 87.6 and $88.3 \%$ for river of Class III and Class IV, respectively, as well as 57.6 and $62.1 \%$ of total coliform and Escherichia coli, respectively, from Class III river at dosage $196 \mathrm{mg} / \mathrm{L}$ and $\mathrm{pH}$ 4. This study demonstrated that the deshelled Carica papaya seedsderived coagulant is capable in treating common pollutants of river and simultaneously shows antibacterial properties.

Keywords: Antibacterial properties; Carica papaya seeds; deshelled; natural coagulant

\section{ABSTRAK}

Kajian ini menilai kecekapan biji betik terkupas sebagai bahan penggumpal semula jadi untuk meningkatkan kualiti air sungai. Biojisim biji betik terkupas ini kebanyakannya dicirikan untuk kumpulan berfungsi menggunakan FTIR, cas permukaan dan kandungan protein. Ujian penggumpalan dan pemflokulatan telah dijalankan menggunakan ujian kelompok untuk beberapa variasi dos dan nilai pH. Dos dan pH yang optimum telah dikaji untuk merawat sungai kelas III hingga kelas IV. Kumpulan berfungsi biji betik terkupas adalah kumpulan $\mathrm{O}-\mathrm{H}, \mathrm{C}=\mathrm{O}$ dan $\mathrm{C}$-O. Cas permukaan dan kandungan protein masing-masing adalah $+0.4 \mathrm{meq} / \mathrm{g}$ dan $363 \mathrm{mg} / \mathrm{g}$. Penggumpal biji betik terkupas dapat menghilangkan kekeruhan sehingga 87.6 dan 88.3\% untuk sungai kelas III dan kelas IV, berserta menghilangkan kandungan sebanyak 57.6 dan 62.1\% daripada jumlah koliform dan Escherichia coli, dariapada sungai kelas III pada dos $196 \mathrm{mg} / \mathrm{L}$ dan pH 4. Kajian ini menunjukkan bahawa biji Carica papaya terkupas - terbitan penggumpal berkebolehan dalam merawat pencemaran umum di sungai dan secara tidak langsung menunjukkan ciri antibakteria.

Kata kunci: Biji Carica papaya; ciri antibakteria; penggumpal semula jadi; terkupas

\section{INTRODUCTION}

Conventional coagulation process often uses chemical coagulants such as alum and ferric chloride. Despite its establishment in treating water and wastewater, the uses of these chemical coagulants pose numerous adverse effects due to residual coagulant present in the treated water. The residual coagulant is harmful and can deteriorate one's health after long period of consumption (Choy et al. 2014). Also, the operational cost of a treatment using chemical coagulant is high due to its voluminous end sludge production that requires proper treatment (Antov et al. 2010; Hendrawati et al. 2016; Teh et al. 2014). Therefore, the cost of chemical coagulant for water treatment puts a strain on developing countries.

Due to these aforementioned drawbacks, it is now crucial to shift towards the use of natural coagulant. 
The use of natural coagulants in water and wastewater treatment has been commonly practiced and is evidenced to have environmental advantages. Reviews and current practices indicated that Moringa oleifera seeds, Nirmali seeds, tannin and Opuntia ficus cactus are the most popular precursors for natural coagulant production (Amran et al. 2018; Choy et al. 2014; Yin 2010). Continuing efforts to diversify the choice of natural coagulants and to explore other potential natural coagulants would be beneficial in terms of achieving the goal of waste minimization and seeking better water and wastewater treatment approaches.

Carica papaya, commonly called papaya, is a popular fruit especially in tropical countries like Malaysia. In 2017, Department of Agriculture, Malaysia recorded that as much as 83,797 tonnes of papaya were harvested (Department of Agriculture 2017). Consumption of papaya fruits results in mass production of food waste. Expectedly, processing of papaya will produce $8.5 \%$ of peels, $6.5 \%$ of seeds and $32 \%$ unusable pulp (Sagar et al. 2018). Hence, action must be taken to minimize the quantity of food wastes resulted from the consumption of papaya fruit. Numerous studies have been conducted on utilization of papaya peels and seeds as natural coagulant for both water and wastewater treatment (Kristianto et al. 2018a; Unnisa \& Bi 2018; Yongabi et al. 2011). Maurya and Daverey (2018) used papaya seed powder to treat municipal wastewater. The results were significant on the TSS (66.7\%) and COD (66.7\%) removals. Papaya seeds have also been used to treat synthetic textile wastewater of drimarene dark red (DDR) (Kristianto et al. 2018a). In the study, the colour was removed up to $84.8 \%$ under the optimum dosage of papaya seeds of $0.57 \mathrm{~g} / \mathrm{L}$ and at $\mathrm{pH}$ 1.97. Despite of the increase exploration of the papaya seeds, most of its usage used the seeds as its whole. Very lack of studies has been reported on the use of deshelled papaya seeds as the coagulant. Deshelled seeds are believed to contain more active coagulant agent that can destabilize the particles upon coagulation treatment process.

To date, a lack of study has been done regarding the potential use of deshelled Carica papaya seeds as the natural coagulant. Knowledge of the role of physical characteristics such as protein content and efficiency in removing turbidity and enabling coagulation remain lacking. Therefore, this study is carried out to explore the feasibility of Carica papaya seeds-derived natural coagulant in treating river water of different classes.

\section{MATERIALS AND METHODS}

\section{PREPARATION OF Carica papaya SEEDS}

Carica papaya seeds were washed prior to the removal of surface membrane layer using a cloth. The seeds were then deshelled and left to dry in an oven for $24 \mathrm{~h}$ at $50{ }^{\circ} \mathrm{C}$. The dried seeds were crushed to a fine powder using a mortar and pestle and the size passing through $0.4 \mathrm{~mm}$ sieve used for tests. Primary processing of natural coagulant was done by mixing $500 \mathrm{mg}$ of Carica papaya seed powder into $500 \mathrm{~mL}$ of distilled water to produce $1 \mathrm{~g} / \mathrm{L}$ of Carica papaya seed-derived natural coagulant.

\section{WATER SAMPLING AND COLLECTION}

The efficiency of Carica papaya seed-derived coagulant were tested on raw polluted river water samples having the quality of Class III, Class IV, and Class V represented by Sungai Skudai, Sungai Melana and Sungai Tukang Batu, respectively. Classifications of rivers in Malaysia are based on National Water Quality Standards (NWQS) as shown in Table 1. The higher the class, the more polluted the river.

TABLE 1. National Water Quality Standard (NWQS) for river in Malaysia (www.doe.gov.my)

\begin{tabular}{|c|c|c|c|c|c|c|}
\hline Parameters & Unit & $\begin{array}{c}\text { Class } \\
\text { I }\end{array}$ & $\begin{array}{c}\text { Class } \\
\text { II }\end{array}$ & $\begin{array}{c}\text { Class } \\
\text { III }\end{array}$ & $\begin{array}{c}\text { Class } \\
\text { IV }\end{array}$ & $\begin{array}{c}\text { Class } \\
\mathrm{V}\end{array}$ \\
\hline Turbidity & NTU & 5 & 50 & & $>50$ & \\
\hline Ammoniacal-nitrogen & $\mathrm{mg} / \mathrm{L}$ & 0.1 & 0.3 & 0.9 & 2.7 & $>2.7$ \\
\hline Total coliform & count $/ 100 \mathrm{~mL}$ & 100 & 5000 & 50000 & 50000 & $>50000$ \\
\hline Faecal coliform & count $/ 100 \mathrm{~mL}$ & 10 & $\begin{array}{c}100 \text { (IIA); } 400 \\
\text { (IIB) }\end{array}$ & $5000(20000)^{*}$ & $\begin{array}{c}5000 \\
(20000)^{*}\end{array}$ & $>$ Class IV \\
\hline
\end{tabular}

* Maximum not to be exceeded 
Water sample was collected during base flow at each location of the rivers. The collected water sample was transferred into new $10 \mathrm{~L}$ double-capped polyethylene bottles prewashed with doubly deionised distilled water. The sample was then preserved with sodium thiosulfate prior to storage at $4{ }^{\circ} \mathrm{C}$.

\section{CHARACTERIZATION OF DESHELLED Carica papaya SEEDS- DERIVED NATURAL COAGULANT}

Carica papaya seed-derived natural coagulant was characterized for surface charge by colloidal titration (Morgan et al. 1990), isoelectric point (Kakoi et al. 2016), protein content (Lowry et al. 1951), and iron content by flame atomic absorption technique, functional groups by Fourier-transform infrared spectroscopy (FTIR) (Shimadzu FTIR 8400, KBr pellet method) and morphological surface structure using field-emission scanning electron microscope (FESEM) (Hitachi TM3000, Quorum Sputter Coater).

\section{COAGULATION-FLOCCULATION TESTS}

Upon obtaining the optimum dosage and $\mathrm{pH}$, coagulation and flocculation batch tests were carried out on synthetic water samples (kaolin) using conventional jar test apparatus at room temperature. Synthetic kaolin water was prepared by mixing $10 \mathrm{~g}$ of kaolin powder into $1 \mathrm{~L}$ of distilled water, followed by mixing at $60 \mathrm{rpm}$ for $20 \mathrm{~min}$ to ensure hydration of the kaolin and subsequent formation of colloids, resulting in a solution with a turbidity of 300 NTU.
The $\mathrm{pH}$ of the water was varied using $1 \mathrm{M} \mathrm{HCL}$ and $\mathrm{NaOH}$. Deshelled papaya seed-derived coagulant was added at dosages of 50-200 $\mathrm{mg} / \mathrm{L}$ and $\mathrm{pH} 4-7$. The mixture was subjected to $250 \mathrm{rpm}$ rapid mixing for $3 \mathrm{~min}$, $30 \mathrm{rpm}$ slow mixing for $15 \mathrm{~min}$, followed by $30 \mathrm{~min}$ of sedimentation time. The turbidity (NTU) of the solution before and after coagulation was measured using a turbidity meter (Milwaukee Turbiditimeter), and the removal was calculated using (1).

$$
\text { Turbidity removal }(\%)=\frac{\text { Initial turbidity }- \text { Final turbidity }}{\text { Initial turbidity }} \times 100
$$

\section{ANALYSIS OF WATER SAMPLES}

The optimum dosage and $\mathrm{pH}$ of deshelled papaya seedsderived coagulant were tested in treating river of Class III to Class V. The coagulation performances of the derived coagulant were determined based on the turbidity, nitrate and coliform removal. These parameters were analysed based on standard method - turbidity (Nephelometry method), nitrate (Method No. 8153) (APHA 2005) and coliform (Colilert method).

\section{RESULTS AND DISCUSSION}

\section{DESHELLED Carica papaya SEEDS CHARACTERIZATION}

Table 2 shows the results for isoelectric point, surface charge, iron and protein content while Figures 1 and 2 show the results for FTIR and FE-SEM, respectively.

TABLE 2. Characteristics of deshelled Carica papaya seeds

\begin{tabular}{lcc}
\hline Parameters & Unit & Value \\
\hline Isoelectric point & $\mathrm{pH}$ & 6 \\
Surface charge & $\mathrm{meq} / \mathrm{g}$ & +0.4 \\
Iron content & $\mathrm{mg} / \mathrm{L}$ & 0.002 \\
Protein content & $\mathrm{mg} / \mathrm{g}$ & 363 \\
\hline
\end{tabular}

Based on Table 2, the recorded isoelectric point for Carica papaya seed-derived natural coagulant was at $\mathrm{pH}$ 6. At this $\mathrm{pH}$, the ions of protein extracted from the natural coagulant are at zero charge. The protein will not attract or repel the negatively charge colloidal particles as it has no charge to do so. Theoretically, if the $\mathrm{pH}$ is below point of zero charge, the acidic solvent will donate protons making it positively charged, and therefore attracting the colloidal particles. However, if the $\mathrm{pH}$ is above point of zero charge, the coagulant surface will be negative, further repelling the colloidal particles (Kukić et al. 2015). Therefore, the Carica papaya seeds would likely be cationic below $\mathrm{pH} 6$. 
The recorded surface charge of the papaya seedderived coagulant was $+0.4 \mathrm{meq} / \mathrm{g}$ (Table 2 ). The positive surface charge implies the positive charge density that can induce flocculation activity. Colloids that are usually negatively charged able to reduce its repulsive force upon reaction with positively charged coagulant (Okaiyeto et al. 2016). Although the value is low, it is possible that the capacity of the Carica papaya seed-derived natural coagulant to ionize would vary at different $\mathrm{pH}$ (Gregory $\&$ Barany 2011). This implies that the surface charge could be greater at certain $\mathrm{pH}$, which will further improve its flocculation ability.

Deshelled Carica papaya seeds also show low concentration of iron content. This justifies that the effectiveness of coagulation performance is because of the effect of the papaya seeds protein as the coagulant and not by iron particles. Meanwhile, the recorded results for protein content of Carica papaya seeds is $363 \mathrm{mg} / \mathrm{g}$. This value is comparable to the study by Amaglo et al. (2010) and Garza et al. (2017) in which an average of $371 \mathrm{mg} / \mathrm{g}$ proteins was extracted from Moringa oleifera. This also means that papaya seeds could possibly have the same amount of natural polyelectrolyte, and thus pose similar coagulation ability as Moringa oleifera.

Figure 1 shows the FTIR spectrum of papaya seeds. From the figure, the absorption at $3000 \mathrm{~cm}^{-1}$ can be linked to $-\mathrm{OH}$ groups while the band at $2925 \mathrm{~cm}^{-1}$ and 2855 $\mathrm{cm}^{-1}$ are relative to the stretching of $\mathrm{OH}$ groups band to methyl group (C-OH) (Gottipati \& Mishra 2010; Kukić et al. 2015). Wavenumber $1747 \mathrm{~cm}^{-1}$ corresponds to $\mathrm{C}=\mathrm{O}$ carbonyl group of carboxylic acid whereas 1657 $\mathrm{cm}^{-1}$ indicates stretching of carboxylic acid $(-\mathrm{C}=\mathrm{O})$ with inter-molecular hydrogen bond (Kakoi et al. 2016). The band at $1466 \mathrm{~cm}^{-1}$ and $1379 \mathrm{~cm}^{-1}$ are comparable to -C-O group (Gottipati \& Mishra 2010). Bands at 1242 and $1163 \mathrm{~cm}^{-1}$ are relative to ether, ester or phenol groups (Kumar \& Ahmad 2011). Ultimately, FTIR analysis on the surface of Carica papaya seeds showed $\mathrm{OH}, \mathrm{C}=\mathrm{O}$ and $\mathrm{C}-\mathrm{O}$ functional groups enable the protein to be a polyelectrolyte.

Figure 2 shows the FESEM image of Carica papaya seeds that have been oven dried and ground into fine powder. From the FESEM image, the papaya seeds showed irregularly shaped with rough and porous surface. The natural coagulant with rough and porous surface is preferable as this indicates the coagulant is having larger surface area. According to Chua et al. (2019) and Cheng et al. (2020), the larger surface area of the coagulant allows more adhesion for interparticle bridging or charge neutralization. To support this justification, the established natural coagulant such as Moringa oleifera also shows similar morphology properties as Carica papaya seeds (Kumar et al. 2014).

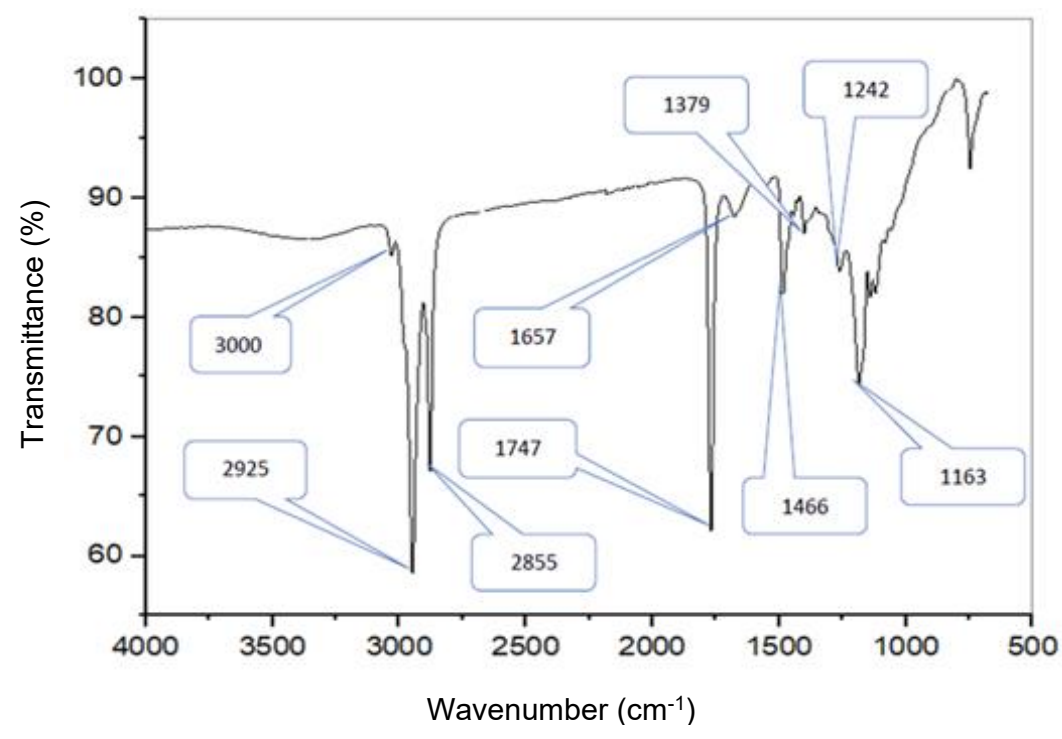

FIGURE 1. Results of FTIR for deshelled Carica papaya seeds 


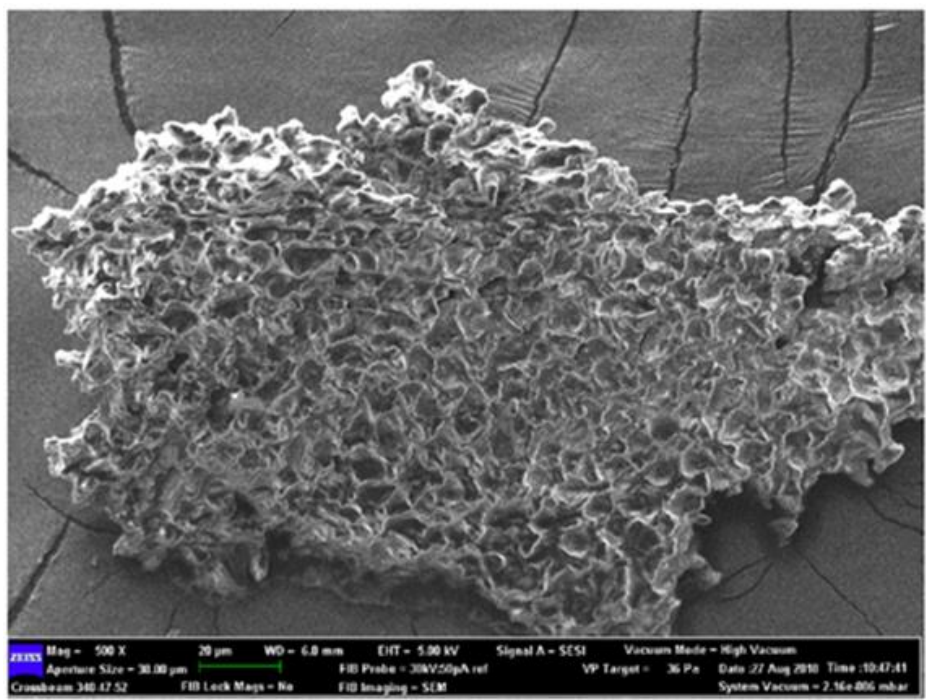

FIGURE 2. FESEM image of Carica papaya seeds after been dried and ground

OPTIMUM DESHELLED PAPAYA SEEDS DOSAGE AND $\mathrm{pH}$ ON THE TURBIDITY REMOVAL

The maximum turbidity removal from the initial 300 NTU of kaolin was obtained as $87.3 \%$ with $196 \mathrm{mg} / \mathrm{L}$ deshelled papaya seeds dosage while the least removal was $54.9 \%$ at a dosage of $50 \mathrm{mg} / \mathrm{L}$ (Figure 3 ). Greater coagulant dosages were marginally more effective than lower doses, which may be attributed to high positive surface charge of the coagulant, thus sufficient for destabilization of colloidal particles (Kakoi et al. 2016; Zaidi et al. 2019).

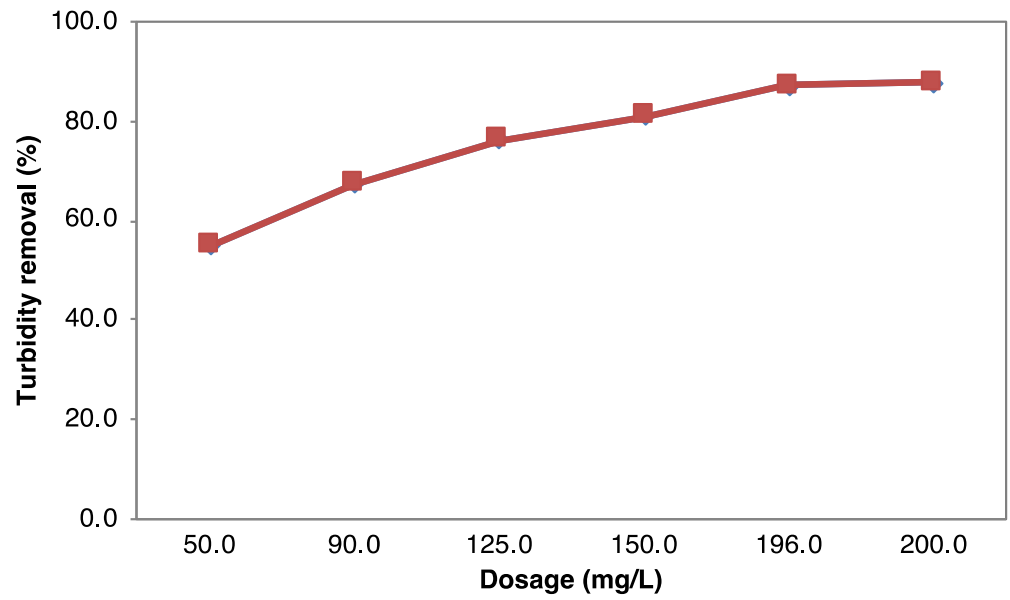

FIGURE 3. Effects of deshelled papaya seed dosage on turbidity removal of kaolin at $\mathrm{pH} 6$ 
Based on Figure 4, the turbidity removal from synthetic kaolin water was found to be greatest at $\mathrm{pH}$ 4, which is in acidic condition. Kristianto et al. (2018b) conveyed that the isoelectric point of kaolin was at $\mathrm{pH}$ 2.8 (acidic). At optimum $\mathrm{pH}$ higher than the isoelectric point, kaolin particle will be negatively charged. On the other hand, the isoelectric point of the active coagulant agent, which is the Carica papaya seeds protein was at $\mathrm{pH} 6$, higher than the optimum $\mathrm{pH}(\mathrm{pH} 4)$. Hence, the papaya seeds protein became the positively charged particle. Therefore, this positively charged natural coagulant removes the negatively charged kaolin by charge neutralization. Removals between differently charged coagulant and pollutant indicated that the coagulation mechanism of the Carica papaya seeds protein is by charge neutralization (Miller et al. 2008).

Nevertheless, based on Figure 4, the turbidity removal beyond the optimum $\mathrm{pH}$ did not show any drastic decrease. According to Kara et al. (2008), there is a possibility that both charge neutralization and interparticle bridging to occur simultaneously. The combined mechanism of the natural coagulant with interparticle bridging manages to remove the pollutants despite of its similar charges (Miller et al. 2008). However, further research is required to further clarify this phenomenon.

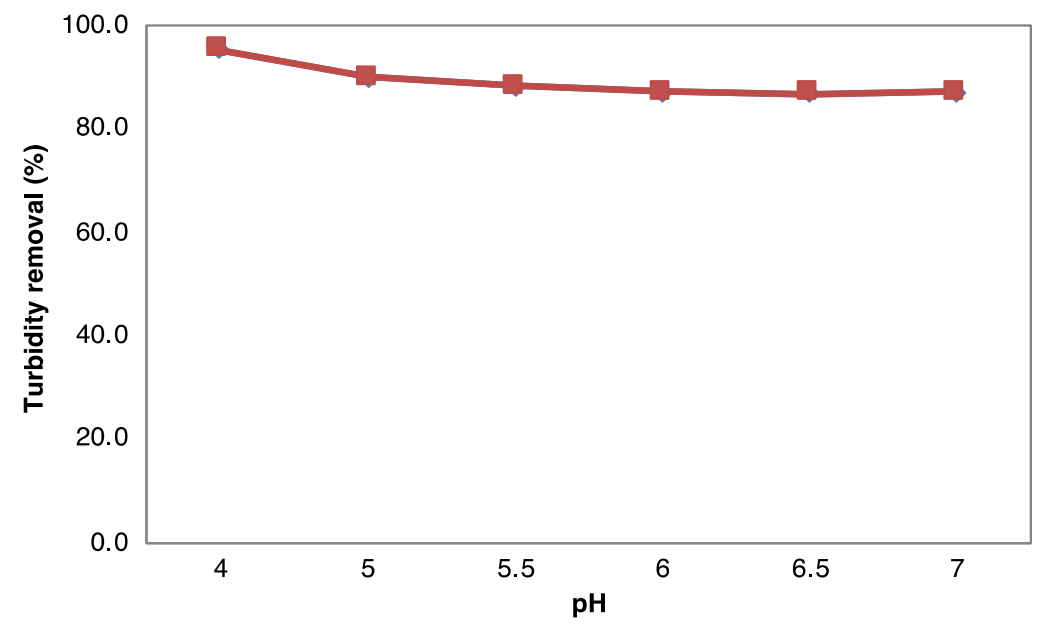

FIGURE 4. Effects of kaolin initial $\mathrm{pH}$ on performance of deshelled papaya seeds $(196 \mathrm{mg} / \mathrm{L})$

EFFECT OF OPTIMUM COAGULATION ON DIFFERENT CLASSES OF RIVER WATER TREATMENT

The trend of contaminant removals for all different classes of river is shown in Table 3. Based on the table, the deshelled Carica papaya seed-derived natural coagulant was effective in treating Class III and Class IV river water at optimum dosage of $196 \mathrm{mg} / \mathrm{L}$ and $\mathrm{pH} 4$.

TABLE 3. Characterization of Sungai Skudai (Class III), Sungai Melana (Class IV) and Sungai Tukang Batu (Class V) before and after coagulation with $196 \mathrm{mg} / \mathrm{L}$ of deshelled papaya seeds at $\mathrm{pH} 4$

\begin{tabular}{lcccccc}
\hline \multirow{2}{*}{ Parameters } & \multicolumn{2}{c}{ Class III } & \multicolumn{2}{c}{ Class IV } & \multicolumn{2}{c}{ Class V } \\
\cline { 2 - 7 } & Before & After & Before & After & Before & After \\
\hline Turbidity (NTU) & $94.0 \pm 19.8$ & $12.6 \pm 11.6$ & $99.7 \pm 10.4$ & $11.6 \pm 0.8$ & $210.0 \pm 46.7$ & $177.5 \pm 54.4$ \\
Nitrite (mg/L) & $11.0 \pm 1.4$ & $1.6 \pm 0.6$ & $27.5 \pm 12.0$ & $1.9 \pm 0.1$ & $40.0 \pm 2.8$ & $38.0 \pm 2.8$ \\
Nitrate (mg/L) & $6.1 \pm 3.3$ & $1.0 \pm 0.3$ & $16.1 \pm 3.3$ & $8.2 \pm 2.3$ & $35.9 \pm 22.5$ & $22.4 \pm 9.1$ \\
\hline
\end{tabular}


The deshelled Carica papaya seed-derived natural coagulant can highly remove turbidity from river of Class III and Class IV. An average of $87.6 \%$ turbidity removal for Class III and $88.3 \%$ turbidity removal for Class IV has been achieved. Nevertheless, the coagulant was found not quite effective in removing turbidity for Class V type of river where only $16.3 \%$ average turbidity removal was achieved. This may be because the turbidity of Class V river (Sungai Tukang Batu) possibly coincided with colour particles or organic matter that have less affinity to coagulate with the deshelled Carica papaya seed-derived natural coagulant (Camacho et al. 2017).

Removal efficiency of nitrate was high for Class III river water with mean removal of $82.3 \%$ followed by Class IV and Class V river water with mean removal of $49.5 \%$ and $32.2 \%$, respectively. High nitrate removal efficiency for Class III river water is because of its lower initial nitrate concentration (below $10 \mathrm{mg} / \mathrm{L}$ ), followed by Class IV (10 $\mathrm{mg} / \mathrm{L}$ to $20 \mathrm{mg} / \mathrm{L}$ ) and Class V (more than $20 \mathrm{mg} / \mathrm{L}$ ) river water. These results imply that the deshelled Carica papaya seeds-derived natural coagulant is efficient in treating water with low initial nitrate concentration.

Nevertheless, upon the use of the deshelled papaya seeds in coagulation treatment, the nitrate concentration of Class III and Class IV river water after the treatment managed to comply with minimum Class II of NWQS for Malaysia. The optimum $\mathrm{pH}$ for removal of nitrite and nitrate is $\mathrm{pH} 4$ while isoelectric point of deshelled Carica papaya seed protein is at $\mathrm{pH} 6$. According to Abidin et al. (2011), at pH less than $\mathrm{pI}$, positively charged amino acids in Carica papaya seeds such as threonine, proline and leucine that make up the protein compound will dominate. Therefore, these positively charged amino acids contribute towards the removal of negatively charged nitrite $\left(\mathrm{NO}_{2}^{-}\right)$ and nitrate $\left(\mathrm{NO}_{3}^{-}\right)$by charge neutralization mechanism.

\section{EFFECT OF OPTIMUM COAGULATION ON ANTIBACTERIAL PROPERTY}

Figure 5 shows the removal trend of Escherichia coli and total coliform. Based on the figure, the deshelled papaya seeds were able to remove $E$. coli and total coliform from Class III types of river water (Sungai Skudai). Based on Figure 5, the mean E. coli and coliform removal for Class III river water was 62.1 and $57.6 \%$, respectively. The removal can be considered high taking into account that no addition of disinfection such as by solar or chlorination takes place throughout the treatment process.

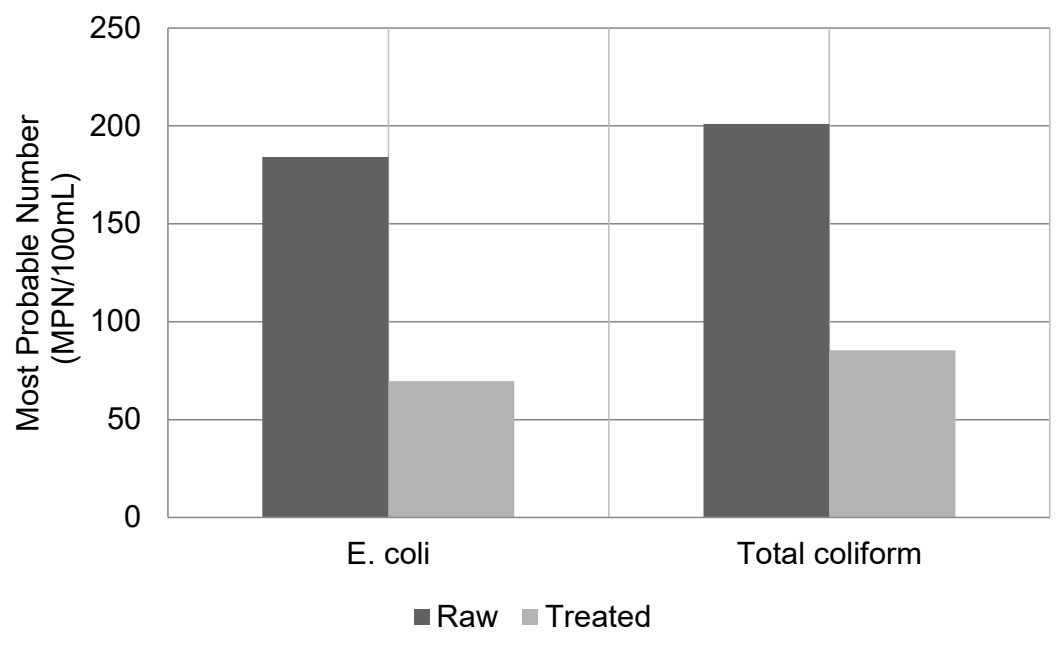

FIGURE 5. Removal of E. coli and total coliforms for river of Class III with $196 \mathrm{mg} / \mathrm{L}$ of deshelled papaya seeds at $\mathrm{pH} 4$

Despite the increase in organic content that may lead to an increase in the microbial activity (Antov et al. 2010), deshelled Carica papaya seed-derived natural coagulant still manages to remove a fair amount of $E$. coli and total coliform from the polluted water. The findings confirmed that the antibacterial properties are inherent in deshelled Carica papaya seeds-derived natural coagulant. Study by Ifesan et al. (2013) showed that phenolic compound may 
be responsible as antibacterial agent for E. coli and total coliform removal. With further extraction and purification, it is believed that deshelled papaya seeds will not only be able to remove pathogens at lower counting but can also remove pathogens of higher counting. According to Peter et al. (2014), conventional extraction by water managed to extract phenolics compound by only with fair amount thus, resulted in average pathogen removal. Alternately, with the extraction of ethanol and hexane, more phenolic compounds were extracted, and better antimicrobial activity were indicated. Instead of phenolics compound, there are other mechanisms that may be involved as antibacterial agent such as antibiotic metabolites and cell wall degrading enzymes (Alo et al. 2012). As to confirm this matter, further study is in need to be carried out to fully identify the exact responsible mechanism of the Carica papaya seeds-derived natural coagulant in disinfecting the water.

\section{CONCLUSION}

The deshelled Carica papaya seeds powder has surface charge value of $+0.4 \mathrm{meq} / \mathrm{g}$ and $363 \mathrm{mg} / \mathrm{g}$ proteins content. FTIR result showed that deshelled papaya seeds powder is mainly composed of $\mathrm{OH}, \mathrm{C}=\mathrm{O}$ and $\mathrm{C}-\mathrm{O}$ functional groups, which enables the protein to be a polyelectrolyte. The FESEM image for deshelled papaya seeds powder shows that its surface structure can facilitate ion absorption with the presence of protein compound. These observations imply that deshelled Carica papaya seeds have the capability to become a natural coagulant.

Deshelled Carica papaya seeds-derived natural coagulant was also effective in treating Class III and Class IV river water at optimum dosage of $196 \mathrm{mg} / \mathrm{L}$ and $\mathrm{pH} 4$. It able to remove turbidity up to 87.6 and $88.3 \%$ for river of Class III and Class IV, respectively, as well as $82.3 \%$ of nitrate for river of Class III. Deshelled Carica papaya seeds-derived coagulant was also able to remove up to 57.6 and $62.1 \%$ of total coliform and E. coli, respectively, from Class III river water, which then verifies the antibacterial properties of the studied coagulant.

\section{ACKNOWLEDGEMENTS}

The authors acknowledge Universiti Teknologi Malaysia (UTM) and the Ministry of Higher Education (MOHE), Malaysia for financing this project via grant $16 \mathrm{~J} 76$ and 5F218, respectively. We also acknowledge Laboratory of Environmental Engineering, School of Civil Engineering at UTM for providing equipment and technical assistance.

\section{REFERENCES}

Abidin, Z.Z., Ismail, N., Yunus, R., Ahamed, I.S. \& Idris, A. 2011. A preliminary study on Jatropha curcas as coagulant in wastewater treatment. Environmental Technology 32(9): 971-977.

Alo, M.N., Anyim, C. \& Elom, M. 2012. Coagulation and antimicrobial activities of Moringa oleifera seed storage at $3^{\circ} \mathrm{C}$ temperature in turbid Water. Advances in Applied Science Research 3(2): 887-894.

Amaglo, N.K., Bennett, R.N., Curto, R.B.L., Rosa, E.A.S., Turco, V.L., Giuffrida, A., Curto, A.L., Crea, F. \& Timpo, G.M. 2010. Profiling selected phytochemicals and nutrients in different tissues of the multipurpose tree Moringa oleifera L., grown in Ghana. Food Chemistry 122(4): 1047-1054.

APHA. 2005. Standard Methods for the Examination of Water and Wastewater. $21^{\text {st }}$ ed. Washington, D.C.: American Public Health Association.

Amran, A.H., Zaidi, N.S., Muda, K. \& Loan, L.W. 2018. Effectiveness of natural coagulant in coagulation process: A review. International Journal of Engineering \& Technology 7(3.9): 34-37.

Antov, M.G., Šćiban, M.B. \& Petrović, N.J. 2010. Proteins from common bean (Phaseolus vulgaris) seed as a natural coagulant for potential application in water turbidity removal. Bioresource Technology 101(7): 2167-2172.

Camacho, F.P., Sousa, V.S., Bergamasco, R. \& Teixeira, M.R. 2017. The use of Moringa oleifera as a natural coagulant in surface water treatment. Chemical Engineering Journal 313: 226-237.

Cheng, S.Y., Show, P.L., Juan, J.C., Ling, T.C., Lau, B.F., Lai, S.H. \& Ng, E.P. 2020. Sustainable landfill leachate treatment: Optimize usage of guar gum as natural coagulant and floc characterization. Environmental Research 188: 109737.

Choy, S.Y., Prasad, K.M.N., Wu, T.Y., Raghunandan, M.E. \& Ramanan, R.N. 2014. Utilization of plant-based natural coagulants as future alternatives towards sustainable water clarification. Journal of Environmental Sciences (China) 26(11): 2178-2189.

Chua, S.C., Malek, M.A., Chong, F.K., Sujarwo, W. \& Ho, Y.C. 2019. Red lentil (Lens culinaris) extract as a novel natural coagulant for turbidity reduction: An evaluation, characterization and performance optimization study. Water 11(8): 1686.

Department of Agriculture (DOA). 2017. Fruit Crop Statistic Malaysia 2017. Putrajaya: Department of Agriculture.

Garza, N.G.G., Koyoc, J.A.C., Castillo, J.A.T., Zambrano, E.A.G., Ancona, D.B., Guerrero, L.C. \& Garcia, S.R.S. 2017. Biofunctional properties of bioactive peptide fractions from protein isolates of Moringa seed (Moringa oleifera). Journal of Food Science Technology 54(13): 4268-4276.

Gottipati, R. \& Mishra, S. 2010. Application of biowaste (waste generated in biodiesel plant) as an adsorbent for the removal of hazardous dye - methylene blue from aqueous phase. Brazilian Journal of Chemical Engineering 27(2): 357-367. 
Gregory, J. \& Barany, S. 2011. Adsorption and flocculation by polymers and polymer mixtures. Advances in Colloid and Interface Science 169(1): 1-12.

Hendrawati, Yuliastri, I.R., Nurhasni, Rohaeti, E., Effendi, H. \& Darusman, L.K. 2016. The use of Moringa oleifera seed powder as coagulant to improve the quality of wastewater and ground water. IOP Conference Series: Earth and Environmental Science 31: 012033.

Ifesan, B.O.T., Fashakin, J.F., Ebosele, F. \& Oyerinde, A.S. 2013. Antioxidant and antimicrobial properties of selected plant leaves. European Journal of Medicinal Plants 3(3): 465-473.

Kakoi, B., Kaluli, J.W., Ndiba, P. \& Thiong'o, G. 2016. Banana pith as a natural coagulant for polluted river water. Ecological Engineering 95: 699-705.

Kara, F., Gurakan, G.C. \& Sanin, F.D. 2008. Monovalent cations and their influence on activated sludge floc chemistry, structure, and physical characteristics. Biotechnology and Bioengineering 100(2): 231-239.

Kukić, D.V., Šćiban, M.B., Prodanović, J.M., Tepić, A.N. \& Vasić, M.A. 2015. Extracts of fava bean (Vicia faba L.) seeds as natural coagulants. Ecological Engineering 84: 229-232.

Kumar, P.S., Centhil, V.M., Kameshwari, R., Palaniyappan, M., Kalaivani, V.D. \& Pavithra, K.G. 2014. Experimental study on parameter estimation and mechanism for the removal of turbidity from groundwater and synthetic water using Moringa oleifera seed powder. Desalination and Water Treatment 57: 5488-5497.

Kumar, R. \& Ahmad, R. 2011. Biosorption of hazardous crystal violet dye from aqueous solution onto Treated Ginger Waste (TGW). Desalination 265: 112-118.

Kristianto, H., Kurniawan, M.A. \& Soetedjo, J.N.M. 2018a. Utilization of papaya seeds as natural coagulant for synthetic textile coloring agent wastewater treatment. International Journal on Advanced Science, Engineering and Information Technology 8(5): 2071-2077.

Kristianto, H., Paulina, S. \& Soetedjo, J.N.M. 2018 b. Exploration of various Indonesian indigenous plants as natural coagulants for synthetic turbid water. International Journal of Technology 3: 466-471.

Lowry, O.H., Rosebrough, N.J., Farr, A.L. \& Randall, R.J. 1951. Protein measurement with the folin phenol reagent. Journal of Biological Chemistry 193: 265-275.

Maurya, S. \& Daverey, A. 2018. Evaluation of plant-based natural coagulants for municipal wastewater treatment. 3 Biotech 8(1): 1-4.

Miller, S.M., Fugate, E.J., Craver, V.O., Smith, J.A. \& Zimmerman, J.B. 2008. Toward understanding the efficacy and mechanism of Opuntia spp. as a natural coagulant for potential application in water treatment. Environment Science Technology 42: 4274-4279.

Morgan, J.W., Forster, C.F. \& Evison, L. 1990. A comparative study of the nature of biopolymers extracted from anaerobic and activated sludges. Water Research 24(6): $743-750$.
Okaiyeto, K., Nwodo, U.U., Okoli, S.A., Mabinya, L.V. \& Okoh, A.I. 2016. Implications for public health demand alternatives to inorganic and synthetic flocculants: Bioflocculants as important candidates. Microbiology Open 5(2): 177-211.

Peter, J.K., Kumar, Y., Pandey, P. \& Masih, H. 2014. Antibacterial activity of seed and leaf extract of Carica papaya var. Pusa dwarf Linn. Journal of Pharmacy and Biological Sciences 9(2): 29-37.

Sagar, N.A., Pareek, S., Sharma, S., Yahia, E.M. \& Lobo, M.G. 2018. Fruit and vegetable waste: Bioactive compounds, their extraction, and possible utilization. Comprehensive Reviews in Food Science and Food Safety 17(3): 512-531.

Teh, C.Y., Wu, T.Y. \& Juan, J.C. 2014. Optimization of agroindustrial wastewater treatment using unmodified rice starch as a natural coagulant. Industrial Crops and Products 56 17-26.

Unnisa, S.A. \& Bi, S.Z. 2018. Carica papaya seeds effectiveness as coagulant and solar disinfection in removal of turbidity and coliforms. Applied Water Science 8(6): $1-8$.

Yin, C.Y. 2010. Emerging usage of plant-based coagulants for water and wastewater treatment. Process Biochemistry 45(9): $1437-1444$

Yongabi, K.A., Lewis, D.M. \& Harris, P.L. 2011. Indigenous plant-based coagulants/disinfectants and sand filter media for surface water treatment in Bamenda, Cameroon. African Journal of Biotechnology 10(43): 8625-8629.

Zaidi, N.S., Muda, K., Abdul Rahman, M.A., Sgawi, M.S. \& Amran, A.H. 2019. Effectiveness of local waste materials as organic-based coagulant in treating water. IOP Conference Series: Materials Science and Engineering 636: 012007.

Amir Hariz Amran, Nur Syamimi Zaidi*, Khalida Muda \& Muhammad Burhanuddin Bahrodin

School of Civil Engineering

Faculty of Engineering

Universiti Teknologi Malaysia

81310 Skudai, Johor Darul Takzim

Malaysia

Liew Wai Loan

UTM School of Professional and Continuing Education (UTMSPACE)

81310 Skudai, Johor Darul Takzim

Malaysia

*Corresponding author; email: nursyamimi@utm.my

Received: 27 August 2020

Accepted: 31 October 2020 